Mohamad Ilmee Mohamad Zin ${ }^{1}$ *

Mariani Md Nor ${ }^{2}$

\title{
Father Involvement, Early Intervention Program and Well-being of Children with Special Needs
}

Abstract

\begin{abstract}
The scenario of the issues that father involvement, early intervention program and well-being of children with special needs have led to be studied. Therefore, this study was to examine whether the three factors or constructs or variables has direct, indirect and intermediary relationship (mediator) using Partial Least Squares Structural Equation Modelling (PLS-SEM) with SmartPLS 3.2.3 software. 158 samples of fathers who have children with special needs aged 4 to 8 years have answered the questionnaires for survey research. In addition, the results of this study prove that measures seven item in three constructs is significant and is suitable for Well-being of Children with Special Needs (Child Health, and Child Housing and Environment); Early Intervention Program (Individual Family Service Plan, and Screening); and Father Involvement (Process Thought, Shared Interest, and Time). In conclusion, this research has proved Early Intervention Program as a Mediator, development a Model of Father Involvement in Early Intervention Program for Well-being of Children with Special Needs and the further study in future is scrutinized with emphasis an Early Screening.
\end{abstract}

Keywords: Father involvement, early intervention program, well-being of children with special needs, pls-sem

\section{Introduction}

The scenario of the issues that involve the father involvement, early intervention program and wellbeing of children with special needs have led the father involvement in early intervention program for the well-being of children with special needs to be studied by the researcher with some principles that can support it.

Based on Ecological Theory (Bronfenbrenner, 1979, 1986, 1989); Identity Theory (Erikson, 1968) and the Human Needs Theory (Maslow, 1943, 1998), some key points related to the theoretical framework of this study (Figure 1).

Microsystem in the ecological theory posits that the involvement of more than two parties involved in a place like living at home and canteens in schools can affect each other (Steinberg \& Bornstein, 2011). Therefore, the researcher was hypothesized that based on the ecological theory father involvement has a positive impact on the early intervention program.
Ecological theory linking microsystem also where some aspects of microsystem the most important in a child's life are family, school (care environment) or day care setting and peer or older child (Steinberg \& Bornstein, 2011). In addition, the children spent the longest time, including in large families, in early care and education programs, health care settings and community sites such as neighbourhoods, libraries and playgrounds (Eastman, 2004). The number and quality of relationships the family and education program where a child spends time also has important implications for development (Eastman, 2004). Therefore, the researcher hypothesized that in the ecological theory the early intervention program has a positive effect on well-being of children with special needs.

\footnotetext{
${ }^{1}$ Ph.D. Student, University of Malaya, Faculty of Education, Department of Educational and Counselling Psychology, Kuala Lumpur, MALAYSIA.

e-mail: ilmee@siswa.um.edu.my

*Corresponding Author

2 Ph.D., Associate Proffessor, University of Malaya, Faculty of Education, Department of Educational and Counselling Psychology, Kuala Lumpur, MALAYSIA. e-mail:marianin@um.edu.my
} 


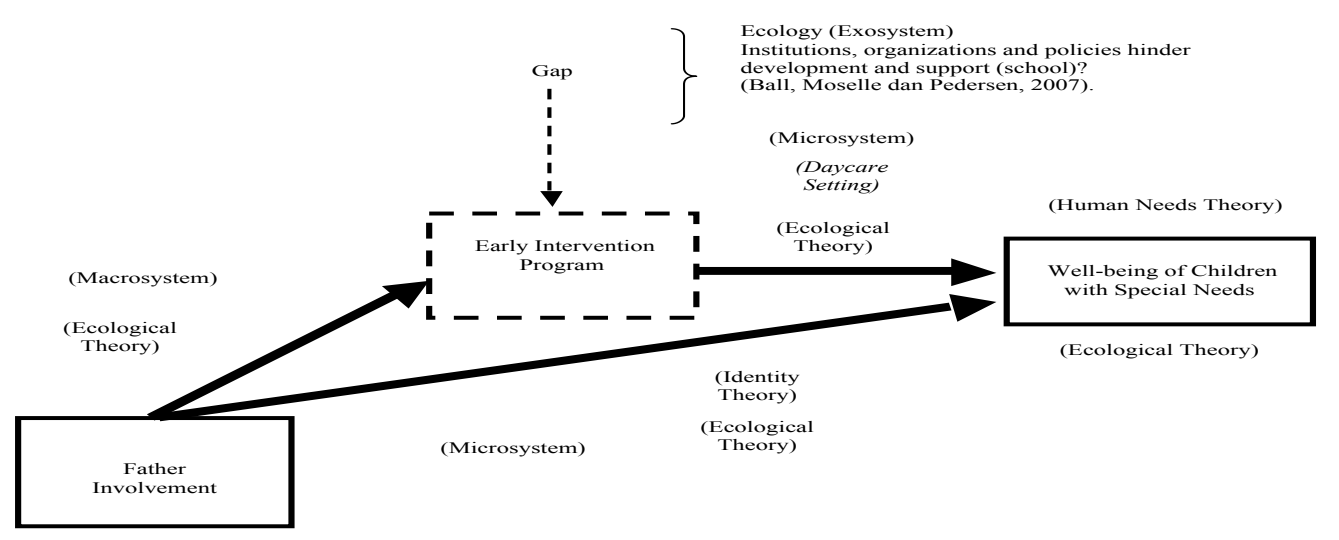

Figure 1.

The theoretical framework of the study.

Ecological theory states that in microsystem available ecological well-being is a concept in which the well-being of the child is determined by the level of parents, families, communities and social well-being (Prilleltensky \& Nelson, 2000). The father involvement is part of the children microsystem (Ball, Moselle \& Pedersen, 2007), and the view of the role of fatherhood and family and cultural interaction through cultural. Besides, macrosystem also affect how involved fathers affect children and families. Children interact with other people, including families (Steinberg \& Bornstein, 2011) and are influenced by parents (Steinberg \& Bornstein, 2011). Identity theory states that the identity can refer to the definition of the individual, including "I'm the father of two sons" (Schwartz, Luyckx \& Vignoles, 2011) and acts as interpersonal between groups and interaction as well as social recognition or otherwise that it received from other individuals or group (Butler, 1990; Reicher, 2000). Therefore, the researcher hypothesized that the father involvement in ecological theory (Ball, Moselle \& Pedersen, 2007; Steinberg \& Bornstein, 2011) has a positive correlation with the wellbeing of children with special needs (Prilleltensky \& Nelson, 2000). The father involvement and well-being of children with special need also has a relationship in identity theory.

Exosystem in ecological theory also clearly states that the institutions, organizations, and policies to hinder or promote development and support (Ball, Moselle \& Pedersen, 2007).
However, previous studies have shown that support in the form of the early intervention program does not preclude the father involvement and well-being of children with special needs. Father involvement and early intervention program are to achieve the final objective of the well-being of children with special needs (Human Needs Theory). Everything a person needs, including children without any conditions to be fulfilled by placing equal rights. Human needs theory applies to adults as well as children with special needs and helping father in a variety of needs and priorities in understanding the ways in which fathers need to support their children's development (Davis, 1992). All these requirements can be found in the Model of Children Needs (Davis, 1992), modified from Maslow (1943).

It is clear that the ecological theory, identity theory and theory of human needs play an important role in forming theoretical studies in this review. Relations between these theories can be seen as a hypothesis in relation father involvement and early intervention program (ecological theory), early intervention program and well-being of children with special needs (ecological theory and human needs theory), and father involvement and well-being of children with special needs (ecological theory, identity theory, and human needs theory) as well early intervention program as study of gap through father involvement $->$ early intervention program -> well-being of children with special needs which is considered as an intermediary for the study. 
Therefore, the general objective of this study was to examine whether the three factors or constructs or variables, namely father involvement, early intervention program and well-being of children with special needs has direct, indirect and intermediary relationship (mediator). Based on the general objectives, four (4) specific objectives of the study were determined, namely: (a) to identify the influence of father involvement against early intervention program, (b) to identify the influence of the early intervention program against the well-being of children with special needs, (c) to identify the influence of father involvement against the well-being of children with special needs, and (d) to identify early intervention program as an intermediary relationship (mediator) between father involvement and well-being of children with special needs.

\section{Method}

The research methodology was adapted from Systematic Implementation Procedures PLSSEM by Hair et al. (2014) composed of six stages, namely (1). Structural Model Designation, (2). Determination of Measurement Model, (3). Data Collection and Assessment, (4). PLS Path Model Estimation, (5). PLS-SEM Evaluation Results, and (6). PLS-SEM Evaluation Results Structural Model.

Inferential statistics using multivariate analysis Structural Equation Modelling (SEM), better known as PLS-SEM via software SmartPLS 3 (Part B-D in the questionnaire). SEM data analysis is a complex statistical technique popular nowadays in the studies of Social Sciences (Hair et al., 2010). It combines the ability to analyze various statistical analyses such as factor analysis, multiple regression and path analysis simultaneously. Path Analysis contained in SmartPLS 3 software is used to examine the relationship between the independent variables and the dependent variable to answer the research question and achieve the objectives. The data in this study to measurement will be analyzed using SmartPLS 3 software (Ringle et al., 2005).

\section{Population, Sample and Sampling}

The population is observed on a group of fathers who are involved in the early intervention program. The client data of Special
Education Services Center (3PK) as of 30 July 2015 in Malaysia shows that there is a population of 933 fathers who have children with special needs involved in the early intervention program at the Special Education Services Center (3PK) Ministry of Education, Malaysia.

Proposed Sample Size in PLS-SEM (Hair et al., 2014) clarified that needs minimal sample size required to detect the minimum $R^{2}(0.10$, $0.25,0.50$ and 0.75 ) in any construct internal Structural Model for the interests of $1 \%, 5 \%$ and $10 \%$ consider the level used in Statistical Power of $80 \%$ and a certain level of complexity path model PLS (the maximum number of arrows independent variables towards the dependent variable in the build path model PLS). For example, when the maximum number of arrows independent variables in the measurement model (independent variables) to the Structural Model (the dependent variable) is five, one would need either of them 70 observations for the Power of Statistics of $80 \%$ to detect the $\mathrm{R}^{2}$ at least 0.25 (with a $5 \%$ probability of error).

The study also found based on the conceptual framework, the number of independent variables to the dependent variable in the measurement model and structural model is two, each of which requires either of which 158 observation to achieve "statistical power of $80 \%$ for detecting $\mathrm{R}^{2}$ values of at $\geq$ least 0.10 (with a $1 \%$ probability of error).

Most researchers use sampling error of $5 \%$ (significance level $\alpha=0.05$ ) with a 95\% level of confidence. In addition, as a researcher it is also necessary to establish a level of significance of our study we tested the hypothesis for our study. Significant level commonly prescribed in Social Science research is $p<0.05$ (alpha value $\alpha$ ) in addition there are researchers who set the alpha level at 0.001 significant with a $99 \%$ confidence level. Normally also to determine the sample size, researchers can refer Table Sample Size Determination by Krejcie and Morgan (1970) and Cohen et al., (1988). However Krejcie and Morgan (1970) did not discuss directly about the significant level and sampling error compared to Cohen (1988).

Therefore, in this study the researcher have selected 158 samples and adapting the proposed sample size in PLS-SEM for Statistic Power of $80 \%$ (Hair et al., 2014) based on the maximum number of arrows to construct a 
total of two requiring 158 size sample and fix this study is the significant level $p<0.05$ (5\% error) with a confidence level of $95 \%$.

Thus, the sample for this study consisted of 158 fathers of children with special needs aged 4 to 8 years is a limitation of the study involved in the early intervention program in 13 Special Education Services Center (3PK), Division of Special Education, Ministry of Education in entire Malaysia.

Sampling is a research strategy when researchers can obtain information of a population of some individuals or groups who sits on the population (Mohd. Majid, 2009). The main principles that should be observed in the sampling are to obtain a sample that is representative of the population studied. Therefore, in this study the researchers chose a simple random sampling. Simple Random Sampling is the process of taking or using samples when every individual in the population has an equal chance to be selected. Therefore, based on the full list of the individual or the sampling frame for the population under study took a sample of 158 fathers who are characterized by uniform involved in early intervention program has children aged 4 to 8 years.
Researcher found also that aspect that needs attention is the truth involves sampling survey samples meet the characteristics of the study population and of all individuals who have a specific feature or some special features (Noraini, 2013).

Based on data from fathers who have children with special needs, the researcher with the approval of each 3PK officer and father found there were 158 fathers answered a questionnaire study of simple random sampling (Table 1). 158 samples of the fathers was made up of fathers who have children with special needs under 4 years around 21 fathers because the concept of early intervention program is for children with special needs under 4 years including taking 107 fathers who have children with special aged 5 to 6 years and 30 fathers who have children with special needs aged 7 years to 8 years. The selection of a sample of 158 fathers was based on the presence of fathers with their children with special needs active for at least three months, which are also the limitations of these studies.

\section{Table 1.}

Simple random sampling of 158 fathers with children with special needs in 13 Special Education Services Centre (3PK) all state in Malaysia.

\begin{tabular}{|c|c|c|c|c|c|}
\hline \multirow[t]{2}{*}{ States } & \multicolumn{4}{|c|}{$\begin{array}{l}\text { Child Age (Years) / } \\
\text { Simple Random Sampling Father Who Have Children With Special } \\
\text { Needs }\end{array}$} & \multirow[t]{2}{*}{ Total } \\
\hline & 4 & 5 & 6 & $7-8$ & \\
\hline Putrajaya & $1-20(21)$ & & $21-69(48)$ & & 69 \\
\hline Perlis & & $70-77$ (8) & & $78-79(2)$ & 10 \\
\hline Kedah & & & $80-90(11)$ & $91-92(2)$ & 13 \\
\hline Pulau Pinang & & & & $93-96(4)$ & 4 \\
\hline Perak & & & $97-102(6)$ & $103(1)$ & 7 \\
\hline Selangor & & & $104-111(8)$ & $112-114(3)$ & 11 \\
\hline Melaka & & $115(1)$ & $116-120(5)$ & $121-123(3)$ & 9 \\
\hline Johor & & & $124-125(2)$ & $126-128(3)$ & 5 \\
\hline Pahang & & & $129-134(6)$ & $135(1)$ & 7 \\
\hline Terengganu & & & $136-137(2)$ & $138-140(3)$ & 5 \\
\hline Kelantan & & & $141-143(3)$ & $144-145(2)$ & 5 \\
\hline Sarawak & & $146-147(2)$ & $148-150(3)$ & $151-153(3)$ & 8 \\
\hline \multirow[t]{2}{*}{ Sabah } & & & $154-155(2)$ & $156-158(3)$ & 5 \\
\hline & & & & & 158 \\
\hline
\end{tabular}


The number of samples to pre-test and pilot studies each of 30 fathers who have children with special needs aged 9 years and above were taken from a total of 933 fathers except sample the real total of 158 fathers elected to have children with special needs aged 4 years to 8 years.

\section{Survey Research}

Pre Test and Pilot Test. Pre Testing is typically done to measure the extent of the changes that will occur on the dependent variable processed later due to the independent variable (Mohd Majid, 2009). Pratt (1980) explains that the concept of reliability measurement in quantitative methods, particularly the use of a questionnaire pilot study (pilot test) means a test on a small scale (smallscale testing). The Pilot Test was also the beginning of the trial (preliminary trial) before items of the real test are imposed on real samples. The aim of the pilot test is to obtain data from trials transparently through a small group of individuals (Borg \& Gall, 1979). Another objective is to evaluate the consistency (reliability) item from the item level, the objective item, item understanding, usability items and command item itself (Roid \& Haladyna, 1982). Accordingly, the researcher has conducted a pre-test questionnaire containing 277 items in 48 dimensions to 30 fathers in the Early Intervention Program, Special Education Services Centre (3PK), Division of Special Education, Ministry of Education, Malaysia. From the pre-test findings, the researcher assessed the highest mean items using SPSS v22 for each dimension was summarizes only that 52 items were selected to be testing in a pilot study also to another 30 fathers in the Early Intervention Program, Special Education Services Centre (3PK), Division of Special Education, Ministry of Education, Malaysia.

Questionnaire. The study was conducted using questionnaires adapted and developed by researcher from questionnaires and surveys of the literature appropriate to collect data from fathers who have children with special needs involved in the early intervention program.

One set of questionnaire form was adapted and developed by researcher in this study consists of four (4) parts that will be answered by fathers who have children with special needs involved in the early intervention program. These parts are: (a). Section A: Demography of Respondent, (b). Section B: Father Involvement, (c). Section C: Early Intervention Program, and (d). Section D: Wellbeing of Children with Special Needs. This study used a seven point Likert Scale (Vagias, 2006) from 1 (Strongly Disagree), 2 (Disagree), 3 (Somewhat Disagree), 4 (Not Sure), 5 (Somewhat Agree), 6 (Agree) and 7 (Strongly Agree). Section A is related to demography of father. Parts B and D were adaptations of several questionnaires that correspond respectively to the father involvement and wellbeing of children with special needs, while Part $C$ is built from a number of surveys on the literature for the early intervention program.

Father involvement construct as Father Involvement Inventory (Hawkins et al., 2002) had the value $\mathrm{a}=0.95$ (long version) by nine dimension and 35 items and $a=0.94$ (shorter version) by nine dimension and 26 items. Senil (2010) using Father Involvement Inventory by Hawkins et al. (2002) found the value $a=0.86$ by six dimensions and 25 items. The Well-being of Children with Special Needs construct also used the Well-being of Malaysian Family Questionnaire (LPPKN, 2011) recorded a value of $a=0.928$, which has seven dimensions and 123 items (Parent).

Three constructs of father involvement, early intervention program and well-being of children with special needs were identified for this study. Constructs in this study include items adapted and developed from some questionnaires and some related literature review, namely: (a) Father involvement constructs adapted from Father Involvement Inventory (Hawkins et al., 2002); and Father Involvement Survey - Turkish Form (Senil, 2010), (b) Early intervention program constructs developed from previous studies from Module 1: Basic Early Intervention Program by NICHCY (2012); Principles for Effective Parenting Skills Program (Sanders et al., 1999); Effectiveness Quality Intervention Program (Moore et al., 2001); Family Support Program (Schorr, 1997); Principles of Service Provision (Schorr, 2000); and Prevention Program (Fónagy, 2001), and (c). Well-being of children with special needs adapted from the Well-being of Malaysian Family Questionnaire (LPPKN, 2011).

Three constructs of father involvement and well-being of children with special needs 
were derived from a number of questionnaires adapted and early intervention program of the few surveys of literature to develop a questionnaires. A construction item to construct the early intervention program was formed by rational-intuitive approach (Hase \& Goldberg, 1967). Implementation of this approach was based on the subjective opinions of the researcher (Azizah, 2012) and also on other studies. Researcher developed items after being approved by three experts for the construct tentative early intervention program under the Module of Basic Early Intervention Program by NICHCY (2012) and five studies of literature Principles of Effective Parenting Skills Program (Sanders et al., 1999); Qualities of Effective Intervention Program (Moore \& Moore, 2001); Supporting Families Program (Schorr, 1997); Service Delivery Principles (Schorr, 2000); and Prevention Program (Fónagy, 2001).

Validity and reliability construct of assessment questionnaire results described in this study to assess the Reliability of Composite Reliability for Individual Item Reliability, Internal Consistency Reliability and Average Variance Extracted (AVE); and to assess the Validity for Convergent Validity and Discriminant Validity in PLS-SEM.

Composite reliability values have exceeded 0.70 , which is the minimum level (Nunnally \& Bernstein, 1994) for all constructs and not less than 0.80 (Fornell \& Larcker, 1981). Composite reliability value of 0.70 to 0.90 is appropriate (Nunnally \& Bernstein, 1994). However, Cronbach alpha for 3 constructs involved was negligible (Hair et al., 2014) because of values below 0.70 and should reach above 0.70 (Chin 2010). Therefore, composite reliability accepted in PLS-SEM has also measured the value of Cronbach alpha (Barroso et al., 2010). Thus, composite reliability for internal consistency reliability (Nunnally \& Bernstein, 1994) and individual item reliability (Hair et al., 2014) have been met in this particular study especially convergent validity. However, Cronbach alpha values are ignored because composite reliability has been met (Hair et al., 2014).

The values of factor loadings or outer loadings to assess individual items reliability have exceeded 0.708 (Hair et al., 2014) while the reliability of composite exceeds the minimum 0.70 and average variance extracted (AVE) exceeds the minimum 0.50 (Hair et al., 2014). In this study also, values $>0.708$ has been received or maintained (Hair et al., 2014) as the composite reliability (>0.70) and AVE $(>0.50)$ respectively have been met. AVE also exceeds the value 0.50 (Fornell \& Larcker, 1981).

The values of latent variables or constructs are greater than the correlation between the different latent variables (Fornell \& Larcker, 1981) based on Fornell- Larcker Criterion and Cross Loading. In addition, Heterotrait-Monotrait Ratio (HTMT) represents the latest methods in discriminant validity test and its acceptance in the study. This confirms that this questionnaire fulfils the criteria of discriminant validity.

\section{Results}

Based on these findings found that items that represent each construct have suitable reliability or individual item reliability (Hair et al., 2014). There are seven significant items representing three constructs which are wellbeing of children with special needs affected by two items (child health, and child housing and enviroment); early intervention program affected by two items (individual family service plan, and screening); and father involvement influenced by three items (thought process, shared interest, and time).

Those findings of path model (Figure 2) in this study using PLS-SEM via software SmartPLS 3 are significantly based on past studies found in the theoretical framework. Accordingly, the findings of this study prove that measures seven items in three constructs (Table 2) are significant and appropriate to father involvement in the early intervention program for the well-being of children with special needs.

The results showed a positive and significant relationship between father involvement with early intervention program $(B=0.521, p$ $<0.05)$. Results of this study support the findings of previous studies (Dunst et al., 1994; Flippin \& Crais, 2011; IDEA Part C, 2004; 2011; Sloper, 1999; Stalker, 1990) which proves that the relationship between father involvement with early intervention program is positive and significant in the context of the father involvement in the early intervention program. Father involvement clearly play a large role in influencing the existing early intervention program. 


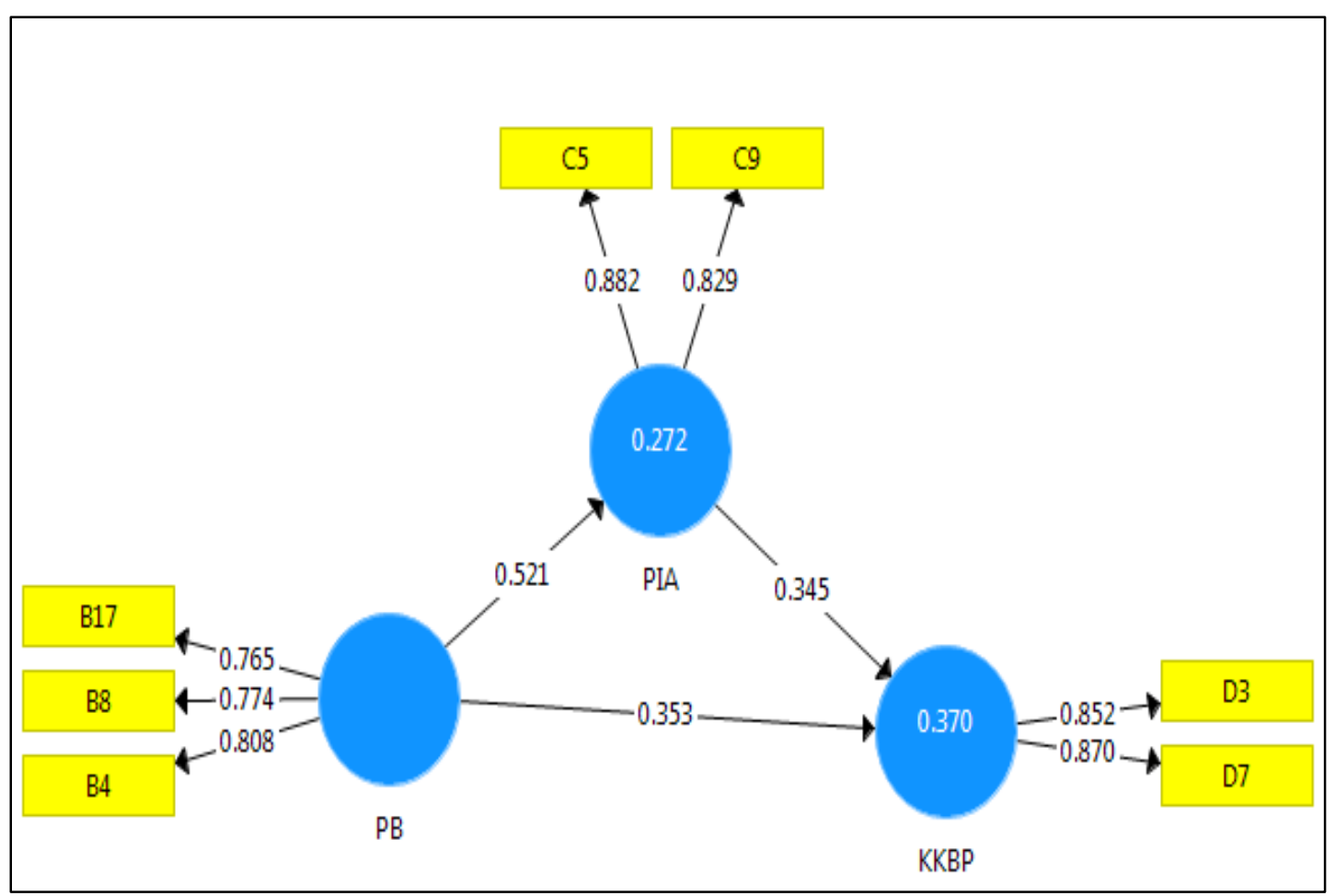

Figure 2.

Findings of path model pls-sem using smartpls 3.2.3 software.

Table 2.

Item represent each statement construct and dimensions.

\begin{tabular}{|c|c|c|c|}
\hline $\begin{array}{l}\text { Constructs } \\
\text { (Latent Variables) }\end{array}$ & $\begin{array}{l}\text { Item } \\
\text { Codes }\end{array}$ & $\begin{array}{l}\text { Item } \\
\text { Delegation (Dimensions) }\end{array}$ & Item Statements (Reflective) \\
\hline \multirow[t]{2}{*}{$\begin{array}{l}\text { Well-being of Children } \\
\text { with Special Needs (KKBP) }\end{array}$} & D3 & Child Health & $\begin{array}{l}\text { I have found in the last } 6 \\
\text { weeks ago my child happy. }\end{array}$ \\
\hline & D7 & $\begin{array}{l}\text { Child Housing and Envi- } \\
\text { ronment }\end{array}$ & $\begin{array}{l}\text { I found the basic facilities in a } \\
\text { residential area so good for } \\
\text { my child. }\end{array}$ \\
\hline \multirow[t]{2}{*}{$\begin{array}{l}\text { Early Intervention Pro- } \\
\text { gram (PIA) }\end{array}$} & $\mathrm{C} 5$ & $\begin{array}{l}\text { Individual Family Service } \\
\text { Plan (IFSP) }\end{array}$ & $\begin{array}{l}\text { I found IFSP need the cooper- } \\
\text { ation of relevant groups to } \\
\text { review the functionality of the } \\
\text { development of children with } \\
\text { special needs. }\end{array}$ \\
\hline & C9 & Screening & $\begin{array}{l}\text { I think that there is any activi- } \\
\text { ty that requires written per- } \\
\text { mission program in my } \\
\text { screening. }\end{array}$ \\
\hline \multirow[t]{3}{*}{ Father Involvement (PB) } & B4 & Thought Process & $\begin{array}{l}\text { I plan for the future of my } \\
\text { child. }\end{array}$ \\
\hline & B8 & Shared Interests & I read with my child. \\
\hline & B17 & Time & $\begin{array}{l}\text { I allocate time just talking } \\
\text { with my child when my child } \\
\text { wants to talk about some- } \\
\text { thing. }\end{array}$ \\
\hline
\end{tabular}


The results of analysis show positive and significant relationship between the early intervention program and well-being of children with special needs ( $\beta=0.345, p<0.05$ ). Results of this study support the findings of previous studies (Dunst, 2007; Dunst, Hamby \& Brookfield, 2007; Holm \& McCartin, 1978; Linder, 1983; Newborg, Stock \& Wnek, 1989; Robinshaw, 1994; See, 1999) which prove that the relationship with the early intervention program with well-being of children with special needs is positive and significant. In the context of the early intervention program against well-being of children with special needs, the early intervention program clearly played a major role in influencing the wellbeing of children with special needs.

Furthermore, the results show a positive and significant relationship between father involvement and well-being of children with special needs ( $B=0.353, p<0.05)$. Results of this study support the findings of previous studies (Dunst, 1985; Gleason, 1975; Flippin \& Crais, 2011; Middleton, 1995; Pellegrini, et al., 1985; Pleck \& Masciadrelli, 2004; Shannon et al., 2002; Sloper, 1999; Sloper \& Turner, 1993; Tannock, 1988) which prove that the relationship of father involvement with wellbeing of children with special needs is positive and significant. In the context of the father involvement against well-being of children with special needs, the father involvement clearly plays a large role in influencing the well-being of children with special needs widely not only in child development.

The analysis results showed the existence of a mediator or intermediary relationships of early intervention program between father involvement and well-being of children with special needs [PB -> PIA (8.895), PB -> KKBP (4.562) and PIA -> KKBP (3.836) is significant, and $\mathrm{PB} \rightarrow \mathrm{KKBP}$ also significant (4.562) and $\mathrm{VAF}=0.50$ (partial mediation)]. Results of this study customize the last adaptation findings (Hebbeler et al., 2007) and prove that the early intervention program must exist as a mediator of the relationship between father involvement and well-being of children with special needs is significant. The importance of the early intervention program as a liaison between father involvement and well-being of children with special needs necessarily the role of the early intervention program should exist between father involvement and wellbeing of children with special needs.

\section{Discussion, Conclusions and Suggestions}

\section{Main Findings}

An early intervention program as a mediator. Previous studies found that in the implementation of the early intervention program has the effect of moderator to progress the development of children with special needs under the age of 3 years (Shonkoff \& HauserCram, 1987) and the father involvement as a moderator in the relationship mother-fatherchild (Rohner \& Veneziano, 2001) in addition to Hebbeler et al. (2007) whoes only mention other services affected by the family and child returns.

Early intervention program as mediator findings in this study has provided intermediate a strong relationship between father involvement and well-being of children with special needs. This is based on evidence upon which the existence of the early intervention program indirectly is necessary to give effect to the well-being of children with special needs. Early intervention program is also a strong link between father involvement and well-being of children with special needs in this study. This study shows that father involvement in early intervention program for the well-being of children with special needs has been proved that the early intervention program is a mediator or intermediary relationship between father involvement and well-being of children with special needs.

\section{Contribution}

Model of Father Involvement in Early Intervention Program for The Well-Being of Children with Special Needs. This model contributes in terms of theory and practice. The contribution of the theoretical aspects in see through the development of models of father involvement, early intervention program and well-being of children with special needs with the addition of several new variables by combining theories such as ecological theory (Bronfenbrenner, 1979, 1986, 1989), theory of identity (Erikson, 1968) and theory of human needs (Maslow, 1943, 1998) that finally developed a Model of Father Involvement in Early Intervention Program for The WellBeing of Children with Special Needs (Figure 3).

Moreover, the discovery of mediator in this study contributes to the increase of existing models. Previously a number of studies 
(Rohner \& Veneziano, 2001; Shonkoff \& Hauser-Cram, 1987) attributed the moderator rather than a mediator in the study of the early intervention program. These findings prove that the early intervention program is the primary contribution between father involvement and well-being of children with special needs. Importance of early intervention program will need support of father involvement for the well-being of children with special needs.

The model is also able to make a practical contribution to the field. This model shows that the father involvement is the strongest variable in influencing early intervention program and well-being of children with special needs different with early intervention program in influencing well-being of children with special needs. This means that the father involvement has a strong influence on the effectiveness of the early intervention program and enhances the well-being of children with special needs.

\section{Future Research}

The implementation of the early intervention program in particular could use model of father involvement in early intervention program for well-being of children with special needs. This model can be expanded in line with the latest findings for Malaysia. The further study in future is scrutinized with emphasis Early Screening (Figure 4) especially for finding children with special needs under the age of 4 years, which has not been involved or dropouts in the early intervention program.

\section{Conclusion}

In conclusion, implementation of qualitative in-depth study with responders of children, mothers, officials in 3PK, policy makers, experts and non-governmental also to be involved with fathers was needed by future researchers to explore indicators of father involvement (process thought, shared interest, and time), early intervention program (individual family services plan and screening), and well-being of children with special needs (child health, and child housing and environment).

\section{Acknowledgements}

This paper was part of a PhD student research which not funded by any organization.

\section{References}

Azizah Sarkowi (2012). Penilaian program praktikum: Model pembentukan dan peningkatan kualiti guru praperkhidmatan di institusi pendidikan guru Malaysia (unpublished doctoral dissertation). Kedah, Universiti Utara Malaysia.

Ball, J., Moselle, K., \& Pedersen, S. (2007, March 1). Father's involvement as a determinant of child health. Paper prepared for The public health agency of Canada, population health fund project: Father involvement for healthy child outcomes. Partners Supporting Knowledge Development and Transfer.

Barroso, C., Carrion, G. C., \& Roldan, J. L. (2010). Applying maximum likelihood and pls on different sample sizes: Studies on servqual model and employee behaviour model. In V. E. Vinzi, W. W. Chin, J. Henseler, \& H. Wang (Eds.), Handbook of partial least squares: Concepts, methods and applications (427448). Heidelberg, Germany: Springer.

Borg, W. R., \& Gall, M. D. (1979). Educational research: An introduction (3rd ed.) New York: Longman.

Bronfenbrenner, U. (1979). Ecology of human development: Experiments by nature and design. Cambridge, MA: Harvard University Press.

Bronfenbrenner, U. (1986). Ecology of the family as a context for human development. Developmental Psychology, 22, 723-742.

Bronfenbrenner, U. (1989). Ecological systems theory. Annals of Child Development, 6, 187-249.

Butler, J. (1990). Gender trouble: Feminism and the subversion of identity. New York, NY: Routledge.

Chin, W. W. (2010). How to write up and report PLS analyses. In V. E. Vinzi, W. W. Chin, J. Henseler \& H. Wang (Eds.), Handbook of Partial Least Squares: Concepts, methods and applications (655690). Heidelberg, Germany: Springer.

Cohen, J. (1988). Statistical power analysis for the behavioral sciences ( $2 \mathrm{nd}$ ed.). Hillsdale, NJ: Lawrence Erlbaum. 


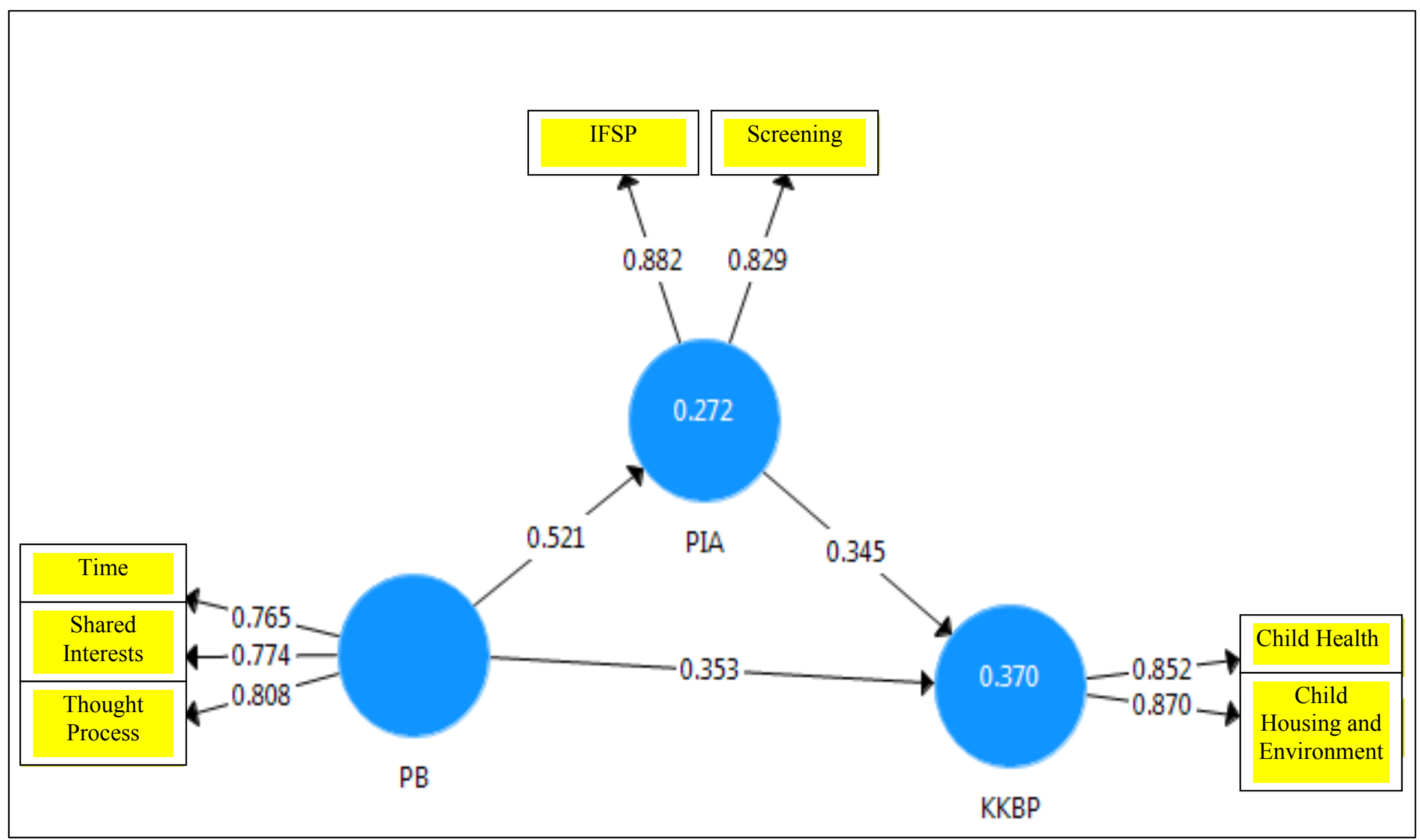

Figure 3.

Model of father involvement in early intervention program for the well-being of children with special needs.

International Journal of Early Childhood Special Education (INT-JECSE), 9(1), 17-30.

DOI: 10.20489/intjecse.330045 


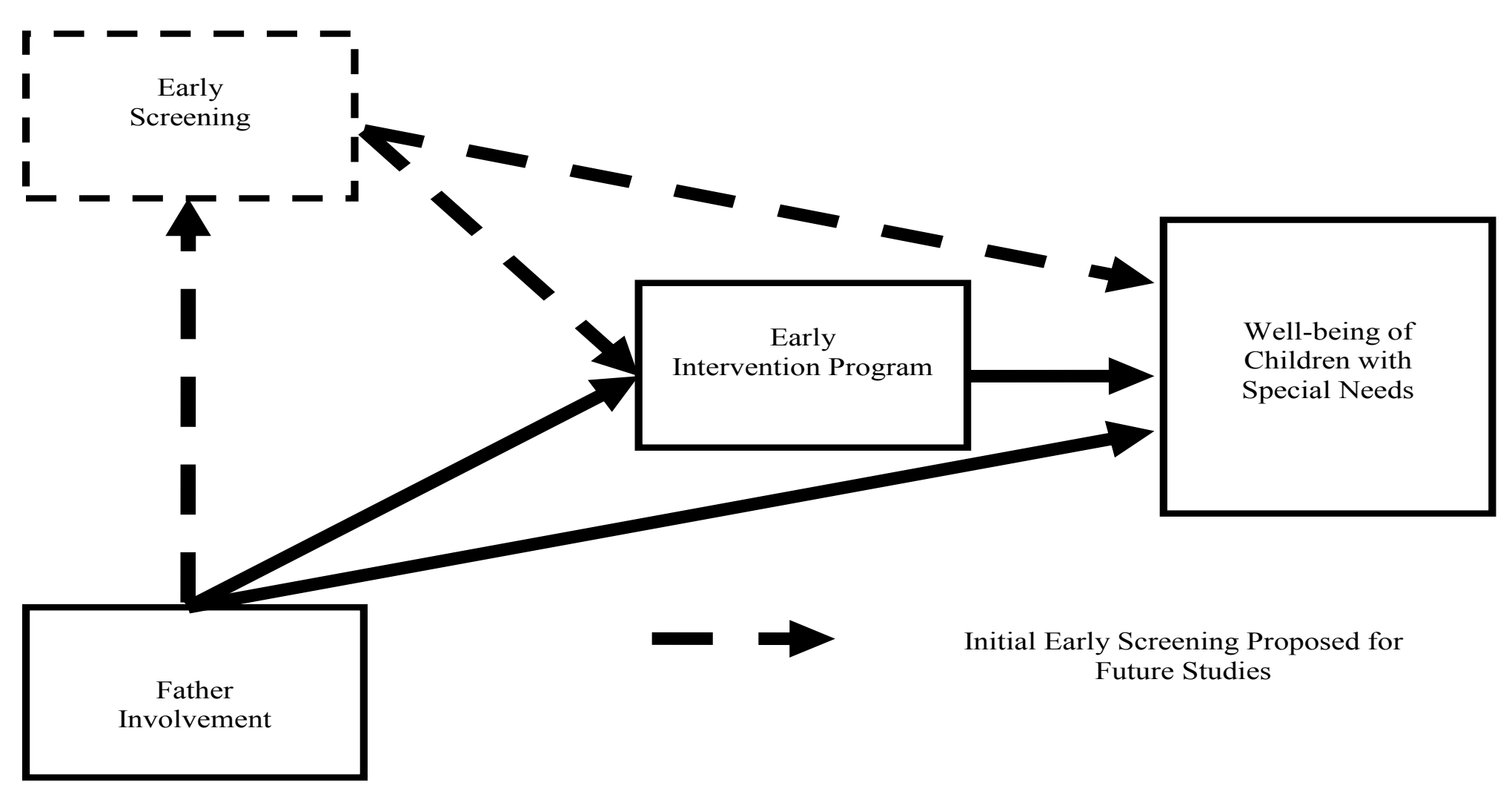

Figure 4.

Conceptual framework of father involvement in early intervention program for the well-being of children with special needs with the addition of early screening construct. International Journal of Early Childhood Special Education (INT-JECSE), 9(1), 17-30. DOI: 10.20489 /intjecse.330045 
Davis, L. L. (1992). Instrument review: Getting the most from your panel of experts. Applied Nursing Research, 53, 314-322.

Dunst, C. J. (1985). Rethinking early intervention. Analysis and Intervention in Developmental Disabilities, 5, 165-201.

Dunst, C. J. (2007). Early intervention with infants and toddlers with developmental disabilities (161-180). In S. L. Odom, R. H. Horner, M. Snell \& J. Blacher (Eds.), Handbook of Developmental Disabilities. New York: Guilford Press.

Dunst, C. J., Hamby, D. W., \& Brookfield, J. (2007). Modelling the effects of early childhood intervention variables on parents and family well-being. Journal of Applied Quantitative Methods, 2(3), 268-288.

Dunst, C. J., Trivette, C. M. \& Deal, A. G. (1994). Supporting and strengthening families: Methods, strategies and practices. Cambridge, MA: Brookline.

Eastman, B. J. (2004). Assessing the efficacy of treatment for adolescent sex offenders: A crossover longitudinal study. Prison Journal, 84(4), 472-485.

Erikson, E. H. (1968). Identity: Youth and crisis. New York: Norton.

Flippin, M., \& Crais, E. R. (2011). The need for more effective father involvement in early autism intervention: A systematic review and recommendation. Journal of Early Intervention, 33(1), 24-50.

Fonagy, P. (2001). Early intervention and prevention: The implications for government and the wider community. Paper presented at The Conference on Attachment and Development-Implications for Clinical Practice. Sydney, Australia, August 2001.

Fornell, C., \& Larcker, D. (1981). Evaluating structural equation models with unobservable variables and measurement error. Journal of Marketing Research, 18(1), 39-50.

Gleason, J. B. (1975). Fathers and other strangers: Men's speech to young children. $26^{\text {th }}$ Annual Roundtable, 289-297

Hair, J. F., Black, W. C., Babin, B. J., \& Anderson, R. E. (2010). Multivariate data analysis (7th ed.). Englewood Cliffs, NJ: Prentice Hall.

Hair, J. F., Hult, G. T, Ringle, C. M \& Sarstedt M. (2014). A primer on Partial Least Squares Structural Equation Modelling
(PLS-SEM). United States of America: SAGE Publications, Inc.

Hase, H. D \& Goldberg, L.R. (1967). The comparative validity of different strategies of deriving personality inventory scales. Psychological Bulletin,67,231248.

Hawkins, A. J., Bradford, P. K., Christiansen, S. L., Palkovitz, R., Day, R. D., \& Call, V. R. (2002). The inventory of father involvement: A pilot study of new measure of father involvement. The Journal of Men's Studies, 10(2), 183196.

Hebbeler, K., Spiker, D., Bailey, D., Scarborough, A., Mallik, S., Simeonsson, R., \& Nelson, L. (2007). Early intervention for infants and toddlers with disabilities and their families: Participants, service and outcomes. In Final Report of the National Early Intervention Longitudinal Study (NEILS). CA: SRI International.

Holm, V. A. \& McCartin, R. E. (1978). Interdisciplinary child development team: Team issues and training in interdisciplinariness (97-122). In E. Allen, V. A. Holm \& R. L. Schiefelbusch (Eds.), Early intervention: A team approach. Baltimore, MD: University Park Press.

Horn, W. F., \& Sylvester, T. (2002). Father facts (4th ed.). Gaitherburg, MD: National Fatherhood Initiative.

Individual with Disabilities Education Act (IDEA, 2004). IDEA part c. Washington, DC: United States Congress.

Individual with Disabilities Education Act (IDEA, 2011). IDEA part c. Washington, DC: United States Congress.

Krejcie, R.V. \& Morgan, D.W. (1970). Determining sample size for research activities. Educational and Psychological Measurement, 30, 607-610.

Lembaga Penduduk Dan Pembangunan Keluarga Negara - LPPKN (2011). Laporan kajian indeks kesejahteraan keluarga Malaysia 2011. Kuala Lumpur, Malaysia: Penerbit LPPKN.

Linder, B. A., \& Siegel, L. S. (1983). Short-term memory process in children with reading and arithmetic learning disabilities. Developmental Psychology, 20, 200207.

Maslow, A. H. (1943). A theory of human motivation. Psychological Review, 50(4), 370-396. 
Maslow, A. H. (1998). Toward a psychology of being (3rd ed.). New York, NY: Wiley.

Middleton, J. A. (1995). A study of intrinsic motivation in the mathematics classroom: A personal constructs approach. Journal for Research in Mathematics Education, 26, 254-279.

Mohd. Majid Konting. (2009). Kaedah penyelidikan pendidikan. Kuala Lumpur: Dewan Bahasa dan Pustaka.

Moore, R.E. \& Moore, T.G. (2003). Working with families of children with developmental disabilities: What makes professionals effective. Paper delivered at 1st International Congress of the International Society on Early Intervention, Rome, 18th-20th September.

National Dissemination Centre for Children with Disabilities - NICHCY (2012). Module 1: The basics of early intervention (Section 3). USA: Department of Education.

Newborg, J., Stock, J. R. \& Wnek, L (1989). Battelle developmental inventory. Allen, TX: DLM.

Nunnally, J. C., \& Bernstein, I. H. (1994). Psychometric theory (3rd ed.). New York, NY: McGraw-Hill.

Pellegrini, A. D., Brody, G. H., \& Siegel, I. E. (1985). Parent's book-reading habits with their children. Journal of Educational Psychology, 77, 332-340.

Pleck, E. H. (2004). Two dimensions of fatherhood: A history of the good dad- bad dad complex (32-57). In M. E Lamb (4 ${ }^{\text {th }}$ ed.), The role of the father in child development. Hoboken, NJ: Wiley.

Pratt, D. (1980). Curriculum design and development. New York: Harcourt Brace Jovanovich, Inc.

Prilleltensky, I., \& Nelson, G. (2000). Promoting child and family's wellness: Priorities for psychological and social interventions. Journal of Community and Applied Social Psychology, 10, 85-105.

Reicher, S. (2000). Against methodolatry: Some comments on Elliott, Fischer, and Rennie. British Journal of Clinical Psychology, 39, 1-6.

Ringle, C. M., Wende, S., \& Will, A. (2005). SmartPLS 2.0 M3. Hamburg: University of Hamburg.

Robinshaw, H. M. (1994). Deaf infants, early intervention, and language acquisition.
Early Child Development and Care, 99, I-22.

Rohner, R. P. \& Veneziano, R. A. (2001). The importance of father love: History and contemporary evidence. Review of General Psychology, 5, 382-405.

Roid, G. H., \& Haladyna, T. M. (1982). A technology for test-item writing. New York, NY: Academic Press.

Sanders, M.R., Tully, L.A., Baade, P., Lynch, M.E., Heywood, A., Pollard, G., \& Youlden, D. (1999). A survey of parenting practices in Queensland: Implications for mental health. Health Promotion Journal of Australia, 9, 112120.

Schorr, L. B. (1991). Successful programs and the bureaucratic dilemma: Current deliberations. New York, NY: National Centre for Children in Poverty.

Schorr, L. B. (1997). Common purpose: Strengthening families and neighbourhoods to rebuild America. New York: Anchor Books, Doubleday.

Schwartz, S. J., Luyckx, K., \& Vignoles, V. L. (2011). Handbook of identity theory and research. New York: SpringerVerlag.

See Ching Mey (1999). A model for early special education in Malaysia (261-283). In Chiam Heng Keng, Fatimah Haron, Mogana Dhamotharan \& Amy Bala. Excellence in Early Childhood Education. Selangor, Malaysia: Pelanduk.

Senil, U. (2010). Being fathered and being a father: Examination of the general pattern of Turkish fathers' and their own fathers' involvement level for children between the ages of 0-8 (Unpublished Master Dissertation) Turkey: Middle East Technical University.

Shannon, J. D., Tamis-LeMonda, C. S., London, K., \& Cabrera, N. (2002). Beyond rough and tumble: Low-income fathers' interactions and children's cognitive development at 24 months. Parenting: Science and Practice, 2, 77-104.

Shonkoff, J. P., \& Hauser-Cram, P. (1987). Early intervention for disabled infants and their families: A quantitative analysis. Paediatrics, 80(5), 650-658.

Sloper, P., \& Turner, S. (1993). Risk and resistance factors in the adaptation of parents of children with severe physical disability. Journal of Child Psychology and Psychiatry, 34,167-188. 
Sloper, P. (1999). Models of service support for parents of disabled children: What do we know? what do us to know? Child: Care, Health and Development, 25, 8599.

Stalker, K. (1990). Share the care: An evaluation of family-based respite care. London: Jessica Kingsley.

Steinberg, L., Vandell, D., \& Bornstein, M. H. (2011). Development: Infancy through adolescence. Belmont, CA: Wadsworth.
Tannock, G. W. (1988). The normal microflora: A new concepts in health promotion. Microbiol. Sci., 5,4-8.

Vagias, W. M. (2006). Likert-type scale response anchors. Clemson, SC: Clemson University, Recreation and Tourism Management, Department of Parks, Clemson International Institute for Tourism and Research Development. 